Dr. M. R. Brown (Signals Research and Development Establishment) gave a brief report on the observation of infra-red quantum counter action in praseodymium doped fluoride lattices at room and liquid nitrogen temperatures. It was hoped to use the reported schemes as a basis for the development of an infra-red detector. Mr. D. M. Clunie (Services Electronies Research Laboratory) reported results of some experiments on helium-neon gas mixtures in which more power was obtained under pulsed conditions than under continuous excitation. This was attributed to the population in the laser terminal level being higher under the continuous excitation. Furthermore, by having two sections separately pulsed at $2.5 \mathrm{kc} / \mathrm{s}$ a continuous output at $0.25-\mathrm{W}$ mean level was obtained. Doubling of the infra-red outputs in ammonium dihydrogen phosphate to give a yellow spot was announced. Mr. J. Smith (Mullards) reported gain measurements made in heliumneon gas mixtures using the $1 \cdot 15 \mu$ laser line. It was found that the optimum gain in the negative glow region of a cold-cathode glow discharge within a hollow cathode was achieved at much higher pressure (20-mm mercury) and higher helium to neon ratios $(1,280: 1)$ than those used in radiofrequency or direct-current positive column excited devices.

Dr. E. L. Thomas (Signals Research and Development Establishment) oxplained the stimulated Raman effect and its use in the generation of radiation. When benzene is placed inside the resonant cavity of a ruby laser, stimulated Raman radiation is produced $991 \mathrm{~cm}^{-1}$ away from the ruby frequency. A second Raman radiation can also be generated approximately $1,982 \mathrm{~cm}^{-1}$ away. The submillimetre radiation, in this case $0.01 \mathrm{~mm}$, would then be generated by mixing the Raman radiation with the ruby radiation.

Dr. D. H. Martin (Queen Mary College) reviewed the kinds of spectra that can be observed in solids with submillimetre radiation. These ranged from lattice absorptions in ionic lattices ( $30 u$ for lithium fluoride) to antiferromagnetic resonance ( $1 \cdot 2 \mathrm{~mm}$ for manganous fluoride). M. R. BROWN

\title{
THE GEOLOGISTS' ASSOCIATION
}

CEVERAL important geological finds made during S 1963 were among the exhibits shown at the annual reunion of the Geologists' Association held in the Large Hall of Chelsea College of Science and Technology on November 2.

The most outstanding of these discoveries was the remains of a large plioseur from the Oxford Clay exhibited by the Department of Palæontology, British Museum (Natural History). This comprised a right-hand paddle $7 \mathrm{ft} .6$ in. in length. Many pliosaurs have been found in the Oxford Clay especially near Peterborough ${ }^{1}$. However, complete specimens of large pliosaurs lying in situ are rarely come by. It is thought their size prevented them from quickly sinking in the mud and hence they were eaten by thoir fellow scavengers. The pliosaur was found in the London Brick Company's clay pits at Stewartby, Bedfordshire, during June 1963, but the front half of the reptile had been taken away by the digger before the bones were noticed. Some of thom were later recovered from the spoil heap by a party from the British Museum (Natural History), and the London Brick Co. has presented the remains to the Museum. It is hoped that the whole reptile will be recovered. The British Museum (Natural History) also showed dinosaurian footprints from the Purbeck, Devonian trilobites from the Spanish Sahara and cobalt pellets from the stomachs of sheep.

In 1961 the longest continuous trackways yet found were discovered in a quarry at Herston on the outskirts of Swanage, and in June 1963 after the overburden had been removed $75 \mathrm{ft}$. of trackway was exposed. Until now it has been generally assumed that these footprints were made by the horbivorous bi-pedal dinosaur, Iquanodon. But, as shown by the exhibit, it is apparent that the birdlike prints forming the main trackway are more akin to a bi-pedal carnivorous dinosaur, such as Megalosaurus. Until recently, trilobite remains were almost unknown from the Spanish Sahara, but during oil exploration work there E. Rod collected almost 30 specimens. The best were given to the British Museum. They came from strata of the Middle Devonian and all belong to the genus Phacops. With the exception of a single specimen they belong to one species, probably new but related to $P$. papulatus from Morocco. The remaining specimen is a related form but is distinguished by a finer ornamentation of the test and a large number of eye facets.

S. E. Ellis (Department of Mineralogy) exhibited phosphate minerals deposited on cobalt pellets from the stomachs of sheep. The sheep is subject to a disease known as 'pining' due to a deficiency of cobalt in herbage. This is combated by either the expensive method of spraying or inserting into the young lamb's stomach a pellet of baked clay impregnated with cobalt oxide.

Ammonites and literature recently acquired in the U.S.S.R. were among the items shown by the Geological Survey and Museum. Ammonites are very important in the identification of zones or sub-zones, which are often named after them. They included the following species from the Upper Aptian of the Lower Greensand (Lower Cretaceous): Parahoplites melchioris, Colombiceras caucasicum and Australiceras ramososeptatum.

J. N. Carreck (Queen Mary College, London) showed specimens, maps, etc., illustrating copperas, as vanished Kentish industry. From about A.D. 1320 until 1914, copperas (an obsolete name for ferrous sulphate or green vitriol) was manufactured from iron pyrites occurring in the London Clay (Lower Eocene) on parts of the coasts of Essex $^{2}$, Kent, Dorset and, perhaps, Hampshire. It was used for the preparation of sulphuric acid, black ink and dye (both as a pigment and a mordant), dressing leather, as a sheep die, for the making of paints-prussian blue (ferric ferrocyanide) and spanish brown (ferric hydroxide), and after refinement was in much demand among both apothecaries and physicians. Mrs. Carreck exhibited photographs of past and present members of the Association.

Dr. G. P. L. Walker (Imperial College of Science and Technology, London) showed several xenoliths of wood collected from Tertiary basalt larvas. He explained how timber, when enclosed in basalt, chars and the basalt is consequently injected into the network of contraction cracks which result. Sometimes the charred wood survives; at other times it is fossilized, for example, replaced by zeolites; or it disappears to leave cavities in the basalt and these may afterwards be infilled with zeolites, etc.

With the west Weald earthquake of October 25 and the Glen Spean earthquake of August 31 still in the news, Dr. A. T. J. Dollar (Birkbeck College, London) exhibited a map illustrating the intensity of the quakes, together with data based on reports from observers of the British Earthquake Enquiry. Other earthquakos demonstrated in the same manner were those occurring in the County of Inverness in 1947 (ref. 3) and the Midlands in 1957 (ref. 4). Together with F. G. Berry, Dr. Dollar also showed a new hand-operated continuous coring tool with a sample core.

A. G. Nicholson showed specimens illustrating tho geology of the Lizard Peninsula. These included the 'serpentine' of the local lapidaries which is the altered 
and attractively coloured part of bastite serpentine found chiefly at quarries near Kennack and Lizard Town, although some of the lapidaries' stock consists of beach boulders. Rare invertebrates obtained from a very large 'pocket' of fossiliferous sand of the Lower Bartonian (Eocene) at Highcliffe, Hampshire, were exhibited by F. C. Stinton. They included a sea urchin Spatangus omalii and bivalves Tellina scalaroides and Abra glabra. The 'pocket' was contained in a very sandy blue clay.

Kingston College of Technology showed rocks collected. in Aberdeenshire at the British Association Mooting and fish from the Lower Old Red Sandstone (Lower Devonian) at Kerrera, near Oban. According to P. R. Gurr (Kingston College) and Dr. L. B. Tarlo (University of Oxford), the fish fauna consisted of Cephalaspis lornensis, as well as a now species of this genus possessing long cornua projecting from the postero-lateral corners of the head shield. Two new cephalaspid genera, also represented, indicated that forms with cornua were not merely primitive animals giving rise to true Cephalaspis, but that they had an important evolutionary development of their own.

Some Tertiary mammals from France were shown by W. H. Bennett, including teeth of Mastodon angustidens from the Helvetian (Middle Miocene) and teeth and jawbone of Lophiodon rhinocerodes, a relative of the tapir, from the Bartonian (Eocene). Other items included: casts of recently described American species of crustaceans, etc., by Mrs. J. I. Collins; Arcoscalpellum comptum, a cirripede new to the Gault (Lower Cretaceous), by J. S. H. Collins; a pyrites nodule from the chalk (Cretaceous) containing a terebratulid by A. Gunner; fossil reptile romains from the Lias (Lower Jurassic) at Ravensear by A. J. R. Snelling; igneous and associated rocks of the Lake District by the Cumberland Geological Society; a cheap method of recording serial sections at minute intervals by F. J. W. Holwill (Imperial College of Science and Technology, London) and new German Devonian fossil finds, etc., by Mr. and Mrs. E. P. Bottley of the wellknown geological firm of Messrs. Gregory, Bottley and Co.

\section{J. L. GLLBERT}

\footnotetext{
Leeds, E. T., The Leeds Collection of Fossil Reptiles from the Oxford Clay of Peterborough, 53 (1956).

'Shenstone, J. T., "Copperas Industry". The Victoria History of the County of Essex, 2, 411 (1907).

${ }^{3}$ Dollar, A. T. J., Nature, 159, 648 (1947)

4 Dollar, A. T. J., Nature, 179, 507 (1957).
}

\section{INSTITUTE OF PERSONNEL MANAGEMENT}

\section{GOLDEN JUBILEE}

$\mathrm{T}$ HE last major ovent in tho Golden Jubilee Year of the Institute of Personnel Management was its annual conference held at Harrogate during October 10-12. Again the attendance was about 1,000, made up of per sonnel and staff managers and directors from many companies throughout the world.

The theme of the conferonce was managoment, productivity and industrial relations, and this was examined by Lord Shawcross in his opening address. He suggested, first, that before advising industry how to organize itself, politicians should set themselves the task of organizing Government itself, for the machinery is cracking to the point of breakdown. The weakest part of the organization is in the formulation of policy. In the old days, perhaps up to the First World War, governmental activity was far less complex than it is to-day, and ministers with ample leisure and small departmental responsibilities were able to cope with problems reasonably satisfactorily. To-day, with vastly increased occasions for governmental intervention, with problems of immense complexity and with heavy departmental pressures, this is far from the case. To-day, policy is settled by debate in a Cabinet consisting of twenty-two members, each armed with a departmental brief and either tending to look at the matter mainly from a departmental point of view or expressing an opinion without much real knowledge of the subject-matter. Any business run in this way would collapse. Efficiency demands a much smaller Cabinet, say perhaps ten people, selected not primarily because they happen to be the heads of particular departments but because they are clearly the best ten people at the Prime Minister's disposal. Among these ten people, the Prime Minister must lead clearly and firmly and accept the responsibility of being the ultimate arbiter of policy. Obviously this arrangement would place on the Prime Minister a heavy burden: he would need assistance much beyond what can at present be given to him by his small private office. He should have, as number two in his Cabinet, as a kind of 'chief of staff', a minister without direct departmental responsibilities, possibly the Lord President or the Lord Privy Seal, whose task it would be to assist the Prime Minister in formulating planning and assessing policies and surveying the main field of govern- mental activity. This minister should himself have a small staff of top-level people, largely drawn from outside the Civil Service and including some possessing what politicians usually lack completely, a trained understanding of the technological age in which we live, who would help to formulate policies having first formed a political view as to what it was desirable and expedient to do.

Turning to industry, Lord Shawcross said that, olthough there are gratifying signs of an upturn in the economy, Britain is not doing well enough. Other countries have accelerated past her. In the past eight years Britain's wages costs have risen about 3 per cent per annum faster than her main competitors; productivity has risen about 3 per cent slower. In those years Britain's export prices went up by 15 per cent; her exports in quantity went up by 32 per cent. In the same period, German prices went up only 5 per cent-but her exports rose in quantity by nearly 200 per cent.

There is need for a supercharger to boost the industrial engine, and this must come from industry. The Government, however, has a part to play in its planning function. Government planning with knowledge of the overall economic picture ought to be of value to industry and there are things which Government can do, as varied as selective capital investment allowances, encouraging particular industries and special housing programmes and resettlement allowances, to encourage mobility of labour. Subject to Government marking out the roads for advance, the self-correcting features of competitive private enterprise should not be destroyed. The supercharger, however, is better management and better industrial relations leading to better productivity. In the past quarter of a century there have been great improvements in standards of management. Nowadays the pattern in big industry is increasingly for the boards of industrial operating companies, as distinct from holding companies, to consist entirely of whole-time executive directors who have worked themselves up to the top. But the standard of management still needs to be raised considerably and management training should be organized not by industry alone, and not by the universities and technical colleges alone, but by both groups in consultation with a full know- 